\title{
Body image and obesity in children from public primary schools in Acapulco, Mexico: A cross-sectional study
}

\author{
Ana I. Casarrubias-Jaimez ${ }^{1}$, José Legorreta-Soberanis ${ }^{1}$, Belén M. Sánchez-Gervacio', \\ Felipe R. Serrano-de los Santos ${ }^{1}$, Sergio Paredes-Solís ${ }^{1}$, Miguel Flores-Moreno ${ }^{1}$, Neil Andersson ${ }^{1,2}$ \\ and Anne Cockcroft',2 \\ ${ }^{1}$ Centro de Investigación de Enfermedades Tropicales, Universidad Autónoma de Guerrero, Acapulco de Juárez, Guerrero, Mexico; ${ }^{2}$ University \\ McGill, Montreal, Canada
}

\begin{abstract}
Background: Childhood obesity is a global problem, causing social and psychological damage, as well as physical health risks. This study estimated the occurrence of body image dissatisfaction in primary schoolchildren aged 9-13 years and investigated its association with obesity and other factors. Methods: A cross-sectional study was conducted, for which 533 students attending three public primary schools in Acapulco were recruited. Students completed a facilitated self-administered questionnaire about their age, sex, socioeconomic level, body image satisfaction, and perception of their parents' body image. We registered anthropometry of the students and calculated body mass index (BMI). We examined the associations of BMI category and other factors with body image dissatisfaction, calculating the cluster-adjusted odds ratio and 95\% confidence intervals. Results: From the total number of participants, 75\% (181/243) of girls and 73\% (170/232) of boys were dissatisfied with their body image and wanted a slimmer body. About half were overweight or obese: 45\% (121/271) of girls and $52 \%$ (135/262) of boys. Overweight or obese children were much more likely to be dissatisfied with their body image (cluster adjusted: 6.73; 95\% Cl: 5.42-8.36). No other factors were significantly associated with body image dissatisfaction. One-third of the girls $(32 \%, 86 / 271)$ and $17 \%$ (45/261) of the boys reported an underweight desired body image. Conclusions: The high level of obesity is a cause for concern and an even higher level of body image dissatisfaction as well. The high dissatisfaction among children suggests that boys, as well as girls in Mexico, may now be subjected to intense social pressure about desirable body image.
\end{abstract}

Key words: Body image dissatisfaction. Body Mass Index. Body Image perception. Obesity. Schoolchildren. Mexico

\section{Imagen corporal y obesidad en escolares de primarias públicas en Acapulco, México: un estudio transversal}

\section{Resumen}

Introducción: La obesidad infantil es un problema global que causa daños sociales, psicológicos y en la salud física. Se estimó la ocurrencia de insatisfacción con la imagen corporal en escolares de 9 a 13 años, y su asociación con la obesidad y otros factores. Métodos: Se realizó un estudio transversal en 533 estudiantes de tres escuelas primarias públicas en

\footnotetext{
Correspondence:

*José Legorreta-Soberanis

E-mail: jlegorreta@ ciet.org

Date of reception: 25-01-2020

Date of acceptance: 08-04-2020

DOI: 10.24875/BMHIM.20000027

Available online: 19-05-2020

Bol Med Hosp Infant Mex. 2020;77(3):119-126

www.bmhim.com

1665-1146/@ 2020 Hospital Infantil de México Federico Gómez. Published by Permanyer. This is an open access article under the CC BY-NC-ND license (http://creativecommons.org/licenses/by-nc-nd/4.0/).
} 
Acapulco, México. Se aplicó un cuestionario autoadministrado sobre edad, sexo, nivel socioeconómico, satisfacción con la imagen corporal y percepción de la imagen corporal de los padres. Se midieron el peso y la talla, y se calculó el índice de masa corporal (IMC). Se examinaron las asociaciones entre el IMC y otros factores con la insatisfacción con la imagen corporal, y se calculó la razón de momios ajustada por conglomerado y sus intervalos de confianza del 95\% (IC 95\%). Resultados: El 75\% (181/243) de niñas y el 73\% (170/232) de niños estaban insatisfechos con su imagen corporal; casi todos deseaban un cuerpo más delgado. El 45\% (121/271) de las niñas y el 52\% (135/262) de los niños presentaba sobrepeso u obesidad, lo que se asoció con la insatisfacción con su imagen corporal (ajustado por clúster: 6.73; IC 95\%: 5.428.36). Ningún otro factor se asoció significativamente con la insatisfacción con la imagen corporal. El 32\% (86/271) de las niñas y el 17\% (45/261) de los niños reportaron una imagen corporal deseada con bajo peso. Conclusiones: El alto nivel de obesidad y el mayor nivel de insatisfacción con la imagen corporal son motivo de preocupación. La insatisfacción sugiere que los niños y las niñas en México pueden verse sometidos a una fuerte presión social sobre la imagen corporal deseable.

Palabras clave: Insatisfacción con la imagen corporal. Índice de masa corporal. Percepción de la imagen corporal. Obesidad. Escolares. México.

\section{Introduction}

Childhood obesity is associated with severe physical health risks; it causes social and psychological problems, including social discrimination, low self-esteem, and depression, and it is linked to eating disorders and distortion of body image perception ${ }^{1,2}$.

Body image is the representation that the mind forms of our own body, the way we perceive our body. It is not related to the actual physical appearance. However, it is conceived from the self-evaluation of the body dimensions through judgments that can construct an alteration of the real body image of an individual ${ }^{3}$. It is made up of the perceptual, cognitive, affective, and behavioral components. The first refers to the appreciation of the body, in whole or in some of its parts; the second, to the appreciation of the body or a part of it; the third, to feelings or attitudes toward the body or a part of it; and the last one refers to actions or behaviors that occur from perception. Some authors refer to the last two as a single component ${ }^{4}$.

The change in beauty standards that occur over the years has influenced the desired body image. Not being able to achieve beauty standards gives rise to the dissatisfaction of the body image. Dissatisfaction occurs when it is concluded that the own body or parts of it do not satisfy the image determined culturally or socially ${ }^{5}$. This process is derived from alterations in the cognitive, affective, and perceptual components. From this, negative feelings can be generated, causing the estimation of the body, size, or shape to be inaccurate. When there is little relationship between what is perceived and dissatisfaction, body image disorders should be considered ${ }^{4}$.

Body image dissatisfaction among children is common. In $\mathrm{Brazil}^{6}$ an investigation reported that $82 \%$ of children between 8 and 11 years of age expressed dissatisfaction with their body image. A study in Yucatan, Mexico, found $70 \%$ of $10-17$-year-old children with body image dissatisfaction?. There is also an association between being overweight or obese and body image dissatisfaction ${ }^{8}$.

Although the human body has been the object of admiration since ancient times, this admiration has changed focus over the years from rounded to thinner figures as a result of sociocultural influences ${ }^{9}$. The commercialized versions of contemporary beauty can impact on young people, and may lead to eating disorders related to body image dissatisfaction and negative self-worth ${ }^{10}$. Self-concern about our body and appearance fuels major industries as social pressure and drives consumption in pursuit of a usually unattainable ideal. As a result, an exaggerated interest in physical appearance arises, sometimes with internal conflict and pathological problems ${ }^{11}$.

Evaluating body image satisfaction in early childhood allows planning actions, such as behavioral changes that are more difficult to modify in older children, adolescents, or adults ${ }^{12}$. The objective of this study was to estimate the occurrence of body image dissatisfaction and its associated factors in schoolchildren from public primary schools in Acapulco, Mexico.

\section{Methods}

A cross-sectional study was carried out between February and March 2017. We recruited schoolchildren from the $4^{\text {th }}$ to $6^{\text {th }}$ grade of three public primary schools in Acapulco, Mexico. We selected, by convenience, schools with similar infrastructure to represent the different socioeconomic levels of schoolchildren in 
Acapulco. Students attending a typical day of classes completed a facilitated self-administered questionnaire. The measurement instrument was previously validated by a panel of experts ${ }^{13}$ : one economist, two epidemiologists, and one pediatrician. In front of the class, the facilitator read aloud each of the 20 questions and the students marked their own response sheets anonimously. The questionnaire included questions about the children's age, educational level, socioeconomic level, self-perception of body image, body image satisfaction or dissatisfaction, perceived body image and desired body image, using the Castro scale ${ }^{14}$, and perception of their parents' bodies using the Stunkard scale $^{15}$.

We assessed socioeconomic level with five questions about the number of people living in their house, the number of rooms (not counting the bathroom and kitchen), the material of the walls and floor, and the appliances and services available (TV, internet, refrigerator, electricity supply, drainage, and drinking water supply). Each question was scored from 0 to 5, giving an overall score from the five-question scale between 0 and 50 . We categorized $0-20$ points as low socioeconomic status, 21-35 as medium, and $36-50$ as high.

For each child, we determined the body mass index (BMI) concerning age and sex. We used BMI reference values proposed by the Centre for Disease Control and Prevention, of the USA, as follows: low weight, below the $5^{\text {th }}$ percentile; normal weight, between the $5^{\text {th }}$ and $85^{\text {th }}$ percentile; overweight, from the $86^{\text {th }}$ to below $95^{\text {th }}$ percentile; and obesity equal to or greater than the $95^{\text {th }}$ percentile ${ }^{16}$. Master's students in epidemiology were trained to measure the height and weight of schoolchildren to calculate BMI. For the determination of the weight, we used an analog weight care scale (model WCS-0410); schoolchildren wore a physical education uniform (shorts and t-shirt) without shoes or accessories. The height of each student was measured with a measuring tape fixed vertically to the wall, positioning the student barefoot, standing straight with their back to the tape, heels together, and knees unbent. Each child received a written report of their anthropometric measurements. The researchers taking the anthropometric measurements were unaware of what body image the students had selected in their questionnaires.

Body image scales have been used to assess the consistency between the perception of body image and the actual BMI, however, seldom to evaluate body image dissatisfaction ${ }^{3,5}$. Body image dissatisfaction is derived from a cognitive process involving comparison, self-evaluation, and self-disgust and it is potentially susceptible to education and guidance ${ }^{17}$. The scale proposed by Castro comprises six silhouettes, numbered sequentially, ranging from thin to fuller body types ${ }^{9}$. The first two silhouettes correspond to underweight, the third to normal weight, the fourth and fifth to overweight, and the sixth to obesity. The students selected two silhouettes: the first as their perceived body image and the second as their desired body image. The degree of body image dissatisfaction was the subtraction of the desired body image value from the perceived body image value, classified as follows: 0 , satisfied; 1 , lightly dissatisfied; 2 , moderately dissatisfied; and $\geq 3$, severely dissatisfied. We categorized students reporting any degree of dissatisfaction as dissatisfied.

To measure concern about body image, we used seven questions divided into two groups. The first group covered concern about being overweight, including the respondents' perception of what others thought about their bodies and whether they wished to lose weight. From these two questions, we created the variable concern, with a value of 1 if the respondent answered either of the two questions positively. The second group of questions covered weight loss practices, asking if the students were reluctant to eat out of fear of gaining weight, whether they intended to lose weight by not eating and whether they had dieted to lose weight. We used these questions to create the variable practices, with a value of 1 if the respondent answered any of the three questions positively.

To measure how the schoolchildren perceived their parents' bodies, we applied the Stunkard scale, which has nine silhouettes ranging from thin to fuller bodies. The first silhouette corresponds to underweight, while the second to fifth represents normal weight, the sixth and seventh, overweight, and the eighth and ninth, obesity.

\section{Data management and analysis}

Data entry relied on EpiData ${ }^{18}$, with double data entry and validation to minimize keystroke errors, and analysis relied on CIETmap ${ }^{19}$. Excluding the few students who were dissatisfied and wanted to have a fuller body image, we conducted a bivariate analysis of factors potentially associated with the outcome of body image dissatisfaction, for each association calculating the odds ratio (OR) and $95 \%$ confidence interval $(95 \% \mathrm{Cl})$, adjusted for clustering ${ }^{20}$. We intended to conduct a subsequent multivariate analysis using the Mantel-Haensze ${ }^{21}$ procedure, including in the initial saturated model factors significantly 
Table 1. Body image dissatisfaction among girls and boys who wanted to be thinner

\begin{tabular}{|l|c|c|c|c|c|c|}
\hline \multirow{2}{*}{ Level of dissatisfaction } & \multicolumn{2}{|c|}{ Girls $(\mathbf{n}=\mathbf{2 4 3})$} & \multicolumn{2}{|c|}{ Boys $(\mathbf{n}=\mathbf{2 3 2})$} & \multicolumn{2}{c|}{ Overall $(\mathbf{n}=\mathbf{4 7 5})$} \\
\cline { 2 - 7 } & $\mathbf{n}$ & $\%$ & $\mathbf{n}$ & $\%$ & $\mathbf{n}$ & $\%$ \\
\hline Satisfied & 62 & 25 & 62 & 27 & 124 & 26 \\
\hline Slightly dissatisfied & 102 & 42 & 87 & 37 & 189 & 40 \\
\hline Moderately dissatisfied & 60 & 25 & 61 & 26 & 121 & 25 \\
\hline Severely dissatisfied & 19 & 8 & 22 & 9 & 41 & 9 \\
\hline
\end{tabular}

*55 students were excluded because they wanted to be fatter.

associated with the outcome in bivariate analysis. However, we did not conduct this analysis because only one factor was significantly associated with the outcome in the bivariate analysis.

\section{Ethical considerations}

We obtained the informed consent from the director of each school, who, in turn, sought the consent of parents for their children to participate. We also obtained an agreement from each child to participate. We handled all information anonymously and confidentially and used it solely for this research. Children were identified only by a unique number identifier. Ethics Committee and Research Committee at the Tropical Diseases Research Centers, of the Autonomous University of Guerrero, approved the study.

\section{Feedback of findings}

We presented the study findings at the three participating schools to the participating students, principals, and teachers. We used non-technical words to present the findings in an appropriate way according to the age of the students and conducted interactive feedback sessions with the students for a better understanding of the information.

\section{Results}

A total of 533 students completed the questionnaire: 54 girls and 67 boys in the first school; 107 girls and 113 boys in the second school; and 110 girls and 82 boys in the third. No student refused to participate in the study. Distribution of participants by age was 9 years old, 19\% (101/533); 10 years old, 31\% (167/533); 11 years old, 32\% (170/533); 12 years old, 17\% (90/533); and 13 years old, $1 \%(5 / 533)$. The average age was 10 years old (standard deviation [SE]: 1.01). Distribution of participants by school grade was as follows: $4^{\text {th }}$ grade, $31 \%(168 / 533) ; 5^{\text {th }}$ grade, $36 \%$ (190/533), and $6^{\text {th }}$ grade, $33 \%(175 / 533)$.

We obtained anthropometric measurements from all children. The average weight of the male students was $43 \mathrm{~kg}$ (SD 13.8), as well as for females (SD 11.1). The average height of female students was $1.43 \mathrm{~m}$ (SD 0.081) and $1.42 \mathrm{~m}$ for males (SD 0.088). The socioeconomic level was distributed in high, 49\% (259/533), medium, $49 \%(262 / 533)$, and low, 2\% (10/533).

Table 1 shows body image dissatisfaction among those 475 students who wanted a slimmer body image. Overall, $74 \%$ (351/475) reported some degree of dissatisfaction; $75 \%$ (181/243) in girls and 73\% (170/232) in boys.

Table 2 shows the BMI category distribution for boys and girls. The overall proportion of schoolchildren with overweight/obesity was 48\% (256/533), 45\% (121/271) in girls, and $52 \%$ (135/262) in boys.

Using the Stunkard scale, $69 \%$ (188/271) of girls and $72 \%(189 / 262)$ of boys perceived their mothers as overweight or obese; and $78 \%$ (214/271) of girls and $81 \%$ (213/262) of boys saw their fathers as overweight or obese.

Most obese girls by BMI are concerned about their body image; all perceive themselves with overweight/ obesity, but only $69 \%$ (34/49) of them did practices for losing weight. In obese boys, the results were similar: most of them are concerned about their body image and perceived to be overweight/obese, and $78 \%$ (58/74) reported losing weight practices. The rest of the nutritional categories and the proportions of concern for body image, perception of body image, and practices for losing weight are shown in Table 2. 
Table 2. Nutritional status in girls and boys, measured by BMI, and proportions of concern about body image, perception of body image, and weight loss practices

\begin{tabular}{|c|c|c|c|c|c|c|c|c|c|c|c|c|c|c|}
\hline & \multirow{2}{*}{\multicolumn{2}{|c|}{$\begin{array}{l}\text { Nutritional status by } \\
\text { BMI }\end{array}$}} & \multirow{2}{*}{\multicolumn{2}{|c|}{$\begin{array}{l}\text { Concerned } \\
\text { about body } \\
\text { image }\end{array}$}} & \multicolumn{8}{|c|}{ Perception of the body image } & \multirow{2}{*}{\multicolumn{2}{|c|}{$\begin{array}{l}\text { Do practices for } \\
\text { losing weight }\end{array}$}} \\
\hline & & & & & \multicolumn{2}{|c|}{ Obese } & \multicolumn{2}{|c|}{ Overweight } & \multicolumn{2}{|c|}{ Normal } & \multicolumn{2}{|c|}{ Underweight } & & \\
\hline & & $\mathbf{n}$ & n & $\%$ & n & $\%$ & n & $\%$ & n & $\%$ & n & $\%$ & n & $\%$ \\
\hline \multirow[t]{4}{*}{ Girls $(n=271)$} & Obese & 49 & 47 & 96 & 2 & 4 & 26 & 53 & 20 & 41 & 1 & 2 & 34 & 69 \\
\hline & Overweight & 72 & 61 & 85 & 1 & 1 & 62 & 86 & 32 & 44 & 6 & 8 & 47 & 65 \\
\hline & Normal & 140 & 119 & 85 & 0 & 0 & 64 & 46 & 58 & 41 & 76 & 54 & 50 & 36 \\
\hline & Underweight & 10 & 8 & 80 & 0 & 0 & 2 & 20 & 2 & 20 & 8 & 80 & 1 & 10 \\
\hline \multirow[t]{4}{*}{ Boys $(n=262)$} & Obese & 74 & 70 & 95 & 6 & 8 & 65 & 88 & 3 & 4 & 0 & 0 & 58 & 78 \\
\hline & Overweight & 61 & 54 & 89 & 1 & 2 & 27 & 44 & 28 & 46 & 5 & 8 & 37 & 61 \\
\hline & Normal & 109 & 92 & 84 & 1 & 1 & 11 & 10 & 68 & 62 & 29 & 27 & 49 & 45 \\
\hline & Underweight & 18 & 15 & 83 & 0 & 0 & 0 & 0 & 6 & 33 & 12 & 67 & 3 & 17 \\
\hline
\end{tabular}

BMI: body mass index.

Table 3. Bivariate analysis of factors associated with body image dissatisfaction

\begin{tabular}{|c|c|c|c|c|c|}
\hline Variable & Categories & Dissatisfied & Satisfied & OR ca & $95 \%$ Cl ca \\
\hline \multirow[t]{2}{*}{ Sex } & Male & 170 & 62 & 0.94 & $0.64-1.38$ \\
\hline & Female & 181 & 62 & & \\
\hline \multirow[t]{2}{*}{ Socioeconomic level } & Medium/low & 174 & 67 & 0.84 & $0.58-1.23$ \\
\hline & High & 176 & 57 & & \\
\hline \multirow[t]{2}{*}{ Age } & $9-10$ years & 170 & 68 & 0.77 & $0.52-1.14$ \\
\hline & $11-14$ years & 181 & 56 & & \\
\hline \multirow[t]{2}{*}{ Body mass index } & Overweight/obese & 225 & 26 & 6.73 & $5.42-8.36$ \\
\hline & Normal/underweight & 126 & 98 & & \\
\hline \multirow[t]{2}{*}{ Perception of mother's body } & Overweight/obese & 252 & 78 & 1.50 & $0.96-2.36$ \\
\hline & Normal/underweight & 99 & 46 & & \\
\hline \multirow[t]{2}{*}{ Perception of father's body } & Overweight/obese & 280 & 98 & 1.04 & $0.77-1.40$ \\
\hline & Normal/underweight & 69 & 25 & & \\
\hline
\end{tabular}

OR ca: odds ratio cluster adjusted; $95 \% \mathrm{Cl}$ ca: $95 \%$ confidence interval cluster adjusted.

Table 3 shows the bivariate analysis of factors associated with body image dissatisfaction. Only BMI overweight/obese category was significantly associated with body image dissatisfaction (odds ratio cluster adjusted [ORca]: $6.73,95 \%$ confidence interval cluster adjusted [95\% Clca]: 5.42-8.36). As only the BMl variable was associated in the bivariate analysis, a multivariate cluster-adjusted analysis was not performed.
Table 4 shows the relationship between the BMI category and the desired body image. Some boys and girls with low weight or normal weight selected an underweight image as their desired body image. All overweight or obese children wished to have a body image with less weight. One-third of the girls $32 \%$ $(86 / 271)$ and $17 \%(45 / 261)$ of the boys selected an underweight image for their desired body image. 
Table 4. BMI category and desired body image proportion among girls and boys

\begin{tabular}{|c|c|c|c|c|c|c|c|c|c|c|}
\hline & \multirow{2}{*}{\multicolumn{2}{|c|}{ BMI category ( $n=530^{*}$ ) }} & \multicolumn{8}{|c|}{ Desired body image } \\
\hline & & & \multicolumn{2}{|c|}{ Underweight } & \multicolumn{2}{|c|}{ Normal } & \multicolumn{2}{|c|}{ Overweight } & \multicolumn{2}{|c|}{ Obese } \\
\hline & & n & n & $\%$ & $\mathbf{n}$ & $\%$ & n & $\%$ & n & $\%$ \\
\hline \multirow[t]{4}{*}{ Girls ( $n=271)$} & Obese & 49 & 34 & 69 & 14 & 29 & 1 & 2 & 0 & 0 \\
\hline & Overweight & 72 & 51 & 71 & 20 & 28 & 1 & 1 & 0 & 0 \\
\hline & Normal & 140 & 105 & 75 & 32 & 23 & 3 & 2 & 0 & 0 \\
\hline & Underweight & 10 & 6 & 60 & 4 & 40 & 0 & 0 & 0 & 0 \\
\hline \multirow[t]{4}{*}{ Boys ( $n=259$ ) } & Obese & 74 & 27 & 36 & 40 & 54 & 6 & 8 & 0 & 0 \\
\hline & Overweight & 61 & 37 & 61 & 20 & 33 & 3 & 5 & 0 & 0 \\
\hline & Normal & 109 & 51 & 47 & 48 & 44 & 9 & 8 & 0 & 0 \\
\hline & Underweight & 18 & 5 & 28 & 12 & 67 & 1 & 6 & 0 & 0 \\
\hline
\end{tabular}

*Three students were excluded because they did not select a desired body image. BMI: body mass index.

Authorities, students, and professors responsible for the participating groups were interested in the feedback of the results of the research. In the end, we asked the children what they could do to help overweight/obese children. The children who raised their hands with suggestions highlighted respect, comradeship, inclusion, empathy, and solidarity.

\section{Discussion}

Three-quarters of the children in our study reported some level of body image dissatisfaction: $40 \%$, slight; $25 \%$, moderate; and $9 \%$, severe dissatisfaction. About one-half of the children were overweight or obese according to their BMI. The BMI obesity category was the only factor associated with body image dissatisfaction.

The level of dissatisfaction in our study is lower $(74 \%)$ than in some others, reporting between 82 and $85 \%$ dissatisfaction among children in similar age groups $^{3,22}$. In our study, no difference was found in the level of dissatisfaction between boys and girls; boys were as dissatisfied as girls. Two reviews noted more significant body image concerns among girls than boys, once the children reached about 8 years old ${ }^{23,24}$. Messages about beauty standards issued by mass media are well recognized for girls ${ }^{25}$. Not finding significant differences in body image dissatisfaction between boys and girls could be explained by the influence of the media and social pressure. Association between sex and body image dissatisfaction still is debatable; a study in the $5^{\text {th }}$ grade students in Canada found that body image dissatisfaction increased with higher BMI in girls but in boys. Those at both extremes of BMI were dissatisfied ${ }^{26}$.

The concept of an "ideal body" differs from social and cultural context ${ }^{27}$. For example, in a study in Brazil ${ }^{3}$, most boys and girls with body image dissatisfaction wanted to be bigger, whereas in our study, nearly all the dissatisfied children, boys as well as girls, wanted to be slimmer.

Overweight and obesity, as indicated by BMI category, are consistently associated with body image dissatisfaction $^{3,4}$; our study also found this association $3,4,28,29$. There are other known associated factors, such as age ${ }^{30}$ and high socioeconomic status $^{31}$, but these associations were not statistically significant in our study. The lack of association with socioeconomic status in our study might be because there was a relatively small range of socioeconomic status among the children; all the schools were public. The narrow age range made the finding of any association with age unlikely in our sample.

Body image concern is influenced by pressure from close family members and the media. Some studies suggest that this pressure can cause eating disorders, beginning in childhood, and continuing into adolescence $^{23,32}$. Concern about body image is manifested in ages 5-9 years and has a close relationship with body image dissatisfaction and obesity/overweight ${ }^{33}$. Information on body image at early childhood is a 
relevant topic for improving the emotional development in children ${ }^{12}$.

The relationship of BMI with the desired body image could identify boys and girls with potential eating disorders $^{34}$. Some boys and girls with normal weight wanted to have a thinner body image, and this is a potential concern.

This study sample reflects only to the population of schoolchildren in the urban area of Acapulco; the schools are located in the same school zone, so the results cannot be generalized to all the population of primary schools in Acapulco, particularly to rural areas. Another disadvantage of our study is the sample size: probably with a larger sample, the statistical significance would have been reached in some of the associated variables.

One of the strengths of this study is that it explores a new topic that requires special attention and shows that it is feasible to take early action in this age group. We believe that feedback to boys, girls, teachers, and school administrators enriches the value of the study.

Feedback strengthened the relationship between the researchers and schools and could be the first step in a future participatory search for solutions to obesity and body image dissatisfaction in students. In one school, teachers selected only overweight children to attend the feedback session, confirming the continued stigma around obesity and body image.

A high level of obesity and a higher level of dissatisfaction with body image in our study are a cause for concern for both educational and health services, family, and society. Equally high levels of dissatisfaction among boys and girls suggest that boys in Acapulco schools may now be subjected to similar social pressures to those experienced by girls.

\section{Acknowledgments}

The authors would like to thank schools and children who agreed to participate in this investigation.

\section{Ethical disclosures}

Protection of human and animal subjects. The authors declare that no experiments were performed on humans or animals for this study.

Confidentiality of data. The authors declare that they have followed the protocols of their work center on the publication of patient data.
Right to privacy and informed consent. The authors have obtained the written informed consent of the patients or subjects mentioned in the article. The corresponding author has this document.

\section{Conflicts of interest}

The authors declare no conflicts of interest.

\section{Funding}

None.

\section{References}

1. Muñoz-Muñoz L, Arango-Álzate C. Childhood obesity: a new approach to its study. Salud Uninorte. 2017;33:492-503.

2. Liria R. Consequences of obesity in children and teenagers: a problem that requires attention. Rev Peru Med Exp Salud Publica. 2012;29:357-60.

3. Vaquero-Cristóbal R, Alacid F, Muyor JM, López-Miñarro PÁ. Imagen corporal: revisión bibliográfica. Nutr Hosp. 2013;28:27-35.

4. García MV, Peresmitré G. Insatisfacción corporal y seguimiento de dieta. Una comparación transcultural entre adolescentes de España y México. Rev Int Psicol Clin Salud. 2003;3:9-21.

5. Salaberria K, Rodríguez S, Cruz S. Perception of corporal image. Biblid. 2007;8:171-83.

6. Pinheiro AP, Giugliani ER. Body dissatisfaction in Brazilian schoolchildren: prevalence and associated factors. Rev Saude Publica. 2006;40:489-96.

7. Oliva-Peña Y, Ordoñez-Luna M, Santana-Carvajal A, Marín-Cárdenas AD, Andueza-Pech G, Gómez-Castillo I. Concordancia del IMC y la percepción de la imagen corporal en adolescentes de una localidad suburbana de Yucatán. Rev Biomed. 2016;2:49-60.

8. Casillas-Estrella M, Montaño-Castrejón N, Reyes-Velázquez V, Bacardí-Gascón M, Jiménez-Cruz A. A mayor IMC, mayor grado de insatisfacción de la imagen corporal. Rev Biomed. 2006;17:243-9.

9. Hernández-Zurivie RM, Rodríguez-Ortiz MD. Psychophysiological reaction to exposure of thin women images in college students. Rev Mex Trastor Aliment. 2011;2:33-41.

10. Kim JH, Lennon SJ. Mass media and self-esteem, body image, and eating disorder tendencies. Cloth Text Res J. 2007;25:3-23.

11. Baile-Ayensa Jl, Guillén-Grima F, Garrido-Landívar E. Insatisfacción corporal en adolescentes medida con el body shape questionnaire (BSQ): efecto del anonimato, el sexo y la edad. Rev Int Psicol Clin Salud. 2002;2:439-50.

12. Facchini M. La preocupación por el peso y la figura corporal en las niñas y adolescentes actuales: ¿de dónde proviene? Arch Argent Pediatr. 2006;104:345-50.

13. Escobar-Pérez J, Cuervo-Martínez A. Validez de contenido y juicio de expertos: una aproximación a su utilización. Av Med. 2008;6:27-36.

14. Sotelo LC. Diseño de Escalas de Siluetas de la Imagen Corporal en Preescolares de Lima [Tesis de Licenciatura]. Lima: Universidad Mayor de San Marcos, Facultad de Medicina; 2014. Available from: http://www. cybertesis.unmsm.edu.pe/bitstream/handle/cybertesis/4154/Castro_sl. pdf?sequence=1\&isallowed=y.

15. Stunkard AJ, Albaum JM. The accuracy of self-reported weights. Am J Clin Nutr. 1981;34:1593-9.

16. Centros Para el Control y la Prevención de Enfermedades. Acerca del Índice de Masa Corporal Para Niños y Adolescentes. Atlanta: Centros Para el Control y la Prevención de Enfermedades; c2015. Available from: https://www.cdc.gov/healthyweight/spanish/assessing/bmi/childrens_bmi/ acerca_indice_masa_corporal_ninos_adolescentes.html.

17. Arranz-Estévez FJ, Aymamí-Sanromá M, Bioque-Alcázar M, Balbuena-Vilarrasa A, Cabrero-Ávila L, Cardonder-Álvarez N. Introducción a la Psicopatología y a la Psiquiatría. Barcelona: Masson; 2011.

18. Lauritsen JM, Bruus M. EpiData, A Comprehensive tool for Validated Entry and Documentation of Data. Odense, Denmark: the EpiData Association; 2003-2005.

19. Andersson N, Mitchell S. Epidemiological geomatics in evaluation of mine risk education in Afghanistan: introducing population weighted raster maps. Int J Health Geogr. 2006;5:1.

20. Lamothe G. Adjusting the mantel haenszel test statistic and odds ratio for cluster sampling. BMC Health Serv Res. 2011;11:S2-15.

21. Mantel N, Haenszel W. Statistical aspects of the analysis of data from retrospective studies of diseases. J Natl Cancer Inst. 1959;22:719-48. 
Bol Med Hosp Infant Mex. 2020;77(3)

22. Zaragoza J, Saucedo T, Fernández T. Asociación de impacto entre factores socioculturales, insatisfacción corporal, e índice de masa corporal en estudiantes universitarios de Hidalgo, México. Arch Latinoam Nutr. 2011;61:207. Available from: https://www. alanrevista.org/ediciones/2011/1/art-3.

23. Ricciardelli LA, McCabe MP. Children's body image concerns and eating disturbance: a review of the literature. Clin Psychol Rev. 2001;21:325-44.

24. Skemp-Arlt KM. Body image dissatisfaction and eating disturbances among children and adolescents. J Phys Educ Recreat Dance. 2006;77:45-51.

25. Salazar-Mora Z. Imagen corporal femenina y publicidad en revistas. Rev Cienc Soc. 2007;2:71-85.

26. Austin SB, Haines J, Veugelers PJ. Body satisfaction and body weight: sex differences and sociodemographic determinants. BMC Public Health. 2009;9:313.

27. Muñiz E. Pensar el cuerpo de las mujeres: cuerpo, belleza y feminidad. Una necesaria mirada feminista. Soc Estado. 2014;29:415-32.

28. Nazrat M, Dawnavan D, Yanovski JA. Body dissatisfaction, self-esteem and overweight among inner-city Hispanic children and adolescents J Adolesc Health. 2005;36:267e16-20.
29. Xanthopoulos MS, Borradaile KE, Hayes S, Sherman S, Veur SV Grundy KM, et al. The impact of weight, sex, and race/ethnicity on body dissatisfaction among urban children. Body Image. 2011;8:385-9.

30. Yanping L, Xiaoqi H, Wenjun M, Guansheng M. Body image perceptions among Chinese children and adolescents. Body Image. 2005;2:91-103.

31. Robinson TN, Chang JY, Haydel KF, Killen JD. Overweight concerns and body dissatisfaction among third-grade children: the impacts of ethnicity and socioeconomic status. J Pediatr. 2001;138:181-7.

32. Cusumo DL, Thompson JK. Media influence and body image in 8-11yearold boys and girls: a preliminary report in the multidimensional media influence scale. Int J Eat Disord. 2001;29:37-44.

33. Davison KK, Markey CN, Birch, LL. A longitudinal examination of patterns in girls' weight concerns and body dissatisfaction from ages 5 to 9 years. Int Eat Disord. 2003:33:320-32.

34. Tylka TL. Relation between body dissatisfaction and eating disorder symptomatology: an analysis of moderating variables. J Couns Psychol. 2004;51:178-91. 